\title{
Overproduction of the yeast STE12 protein leads to constitutive transcriptional induction
}

\author{
Joseph W. Dolan and Stanley Fields \\ Department of Microbiology, State University of New York at Stony Brook, Stony Brook, New York 11794 USA
}

\begin{abstract}
Haploid a and $\alpha$ cells of the yeast Saccharomyces cerevisiae respond to the pheromones $\alpha$ - and a-factor, respectively, by increasing transcription of inducible genes, arresting cell division, and forming cell-surface projections. These responses are dependent on the activity of several genes, including STE12, whose product binds to the pheromone response element located within the regulatory DNA sequences of inducible genes. We assayed the effects of overproducing the STE12 protein in both $S T E^{+}$cells, as well as ste2, ste7, and ste11 mutant cells. We find that overproduction leads to increased transcription of pheromone-inducible genes and is able to suppress the mating defect of the ste mutants. These results suggest that one effect of pheromone treatment may be to increase the ability of the STE12 protein to activate transcription. In addition, we observed that cells cannot tolerate very high levels of the STE12 protein, and many arrest in $G_{1}$ with a large size and morphological changes. Thus, constitutively high-level transcription of pheromone-inducible genes causes cells to display some features similar to treatment with pheromone.
\end{abstract}

[Key Words: Yeast; STE12 protein; pheromone response; transcription; cell-type-specific genes]

Received November 27, 1989; revised version accepted January 25, 1990.

The yeast Saccharomyces cerevisiae exhibits two haploid cell types, designated a and $\alpha$. The a and $\alpha$ cell for mating) types differ from one another in that each transcribes a unique set of genes, the a- and the $\alpha$-specific genes, respectively (for review, see Sprague et al. 1983; Nasmyth and Shore 1987; Herskowitz 1988). These gene sets encode such products as the mating pheromones and the receptors to these pheromones. The response of $a$ and $\alpha$ cells to the appropriate pheromone includes increased transcription of responsive genes, increased agglutinability, arrest of cell division in the $\mathrm{G}_{1}$ phase of the cell cycle, and formation of projections (shmoos) (for review, see Cross et al. 1988). The result of mating between an a and $\alpha$ cell is the third cell type, the $\mathbf{a} / \alpha$ diploid. In the diploid, the a- and $\alpha$-specific sets of genes are repressed, as is the set of haploid-specific genes, which is expressed in both a and $\alpha$ cell types.

The transcriptional regulation of these gene sets is controlled by the products of several genes. The primary level of regulation is conferred by the products of the mating type locus $(M A T)$ (Strathern et al. 1981). In addition, the product of the MCM1 gene, also designated as PRTF (pheromone/receptor transcription factor) or GRM (general regulator of mating type), cooperates with the $M A T$ products in both positive and negative control (Bender and Sprague 1987; Hayes et al. 1988; Keleher et al. 1988; Tan et al. 1988; Jarvis et al. 1989; Passmore et al. 1989). Furthermore, the products of the STE4, STE5, STE7, STE11, and STE12 genes are necessary for cell-type-specific transcription (Hartwell 1980; Fields and Herskowitz 1985; Hartig et al. 1986; Jenness et al. 1987; McCaffrey et al. 1987; Fields et al. 1988). STE4 encodes a subunit of the $G$ protein involved in the signal response pathway (Whiteway et al. 1989), STE7 and STE11 appear to encode protein kinases (Teague et al. 1986; L. Connell and B. Errede, pers. comm.), STE12 encodes a protein that binds to the DNA sequence mediating pheromone response (Dolan et al. 1989; Errede and Ammerer 1989), and the function of STE5 is currently unknown.

The STE genes are required for wild-type levels of expression from the a- and $\alpha$-specific genes, as well as certain haploid-specific genes, although a low level of transcripts is observed even in deletion mutants (Fields et al. 1988). These STE genes are also required for the induction of cell-type-specific expression in response to treatment with pheromone (Hartwell 1980). The level of this induction in response to pheromone varies. Some genes, such as FUS1, are expressed at significant levels only after treatment with pheromone (McCaffrey et al. 1987; Trueheart et al. 1987), whereas others, such as those encoding the pheromones and receptors, are expressed at an enhanced level following treatment (Hagen and Sprague 1984; Nakayama et al. 1985; Hartig et al. 1986). Pheromone induction of transcription might be defective in ste mutants because the STE genes are required for the synthesis of the pheromone response pathway or because they, themselves, are part of the pathway, or 
both (e.g., see Jenness et al. 1987; Fields et al. 1988). Point mutations in the STE genes, some of which lead to only slight reduction in cell-type-specific expression, still have severe effects on mating ability (Hartwell 1980). Thus, the activities of these products are consistent with a role in the transduction of the signal produced by pheromone treatment and not simply in the synthesis of the pathway.

The pheromone response is transmitted via a G protein composed of the products of the GPA1, STE4, and STE18 genes (Dietzel and Kurjan 1987; Miyajima et al. 1987; Jahng et al. 1988; Whiteway et al. 1989). The GPA1 product (the $\alpha$-subunit) negatively regulates response in the absence of pheromone; the STE4 and STE18 products ( $\beta$ - and $\gamma$-subunits, respectively) act positively to trigger response after binding of pheromone. Free $\beta \gamma$-subunits produce an unidentified signal that results in the many changes observed in the pheromonetreated cell. It is still to be determined, however, how these changes are coordinated and where branches in the pathway may occur. Null mutations in the GPA1 gene are recessive haploid lethals because they lead to constitutive response and, hence, cell-cycle arrest (Dietzel and Kurjan 1987; Miyajima et al. 1987), whereas dominant haploid-lethal mutations in STE4 represent constitutive alleles (Blinder et al. 1989). Both of these classes of lethal mutations are suppressed by ste5, ste7, ste11, and ste12 mutations (Nakayama et al. 1988; Blinder et al. 1989), suggesting that these four STE genes act after the G protein.

We have demonstrated previously that the STE12 product (designated here as STE12) plays a critical role in pheromone response by binding to the pheromone response element (PRE) located within the regulatory region of inducible genes (Dolan et al. 1989). The PRE sequence was identified by Kronstad et al. (1987) and Van Arsdell and Thorner (1987) as being sufficient to mediate pheromone induction of transcription. The requirement for STE12 in both uninduced and pheromone-induced transcription suggests that the pheromone response pathway is constitutively active at a low level, perhaps maintaining STE12 in a partially modified state capable of some transcriptional activation. Binding of pheromone may then lead to increased STE12 modification and, thus, increased transcription. In this report, we examine the effects of STE12 overproduction. We find that overproduction leads to increased transcription of the cell-type-specific genes and suppression of the mating defect of other ste mutants. These results suggest that pheromone induction of transcription may be mediated through changes in the activity of STE12.

\section{Results}

Overproduction of STE12 results in increased transcription from pheromone-inducible genes

The STE12 protein, as the factor that binds to the PRE, may be an ultimate target of the signal response pathway triggered by pheromone binding. We reasoned that increased levels of STE12 may lead to transcrip- tional induction in the absence of pheromone, because either the absolute amount of STE12 is normally limiting or the amount of STE12 activated by the constitutive signal through the response pathway is normally limiting. In the latter case, overproduction may lead to increased levels of activated STE12 as a result of the constitutive signal or through the fortuitous activity of proteins (e.g., protein kinases) that normally act on other substrates.

We constructed two kinds of plasmids to overproduce STE12. The first is a multicopy plasmid that carries the STE12 gene expressed from its own promoter, either pSY1 (Dolan et al. 1989) or pSY2, which was derived from $\mathrm{pSY} 1$ by deleting a short region of vector sequences. These plasmids will be designated $2 \mu$-STE12. The second kind of plasmid, designated $\mathrm{P}_{\mathrm{GAL}} \mathrm{STE} 12$, is centromere-containing and carries the STE12 gene expressed from the galactose-inducible GAL1,10 promoter. We introduced these plasmids into $S T E^{+}$strains, isogenic ste 7 and ste 11 single mutants, and a ste 7 ste 11 double mutant (EG123 and 246-1-1 background; Table 1). These strains are $\mathrm{Gal}^{-}$(presumably because of a gal2 mutation) but could be grown on media containing $5 \%$ galactose, albeit much more slowly than $G A L^{+}$strains. Therefore, in addition, we transformed $\mathrm{P}_{\mathrm{GAL}} \mathrm{STE} 12$ into a $\mathrm{GAL}^{+} S T E^{+}$background (W303-1A; Table 1).

The presence of $2 \mu$-STE12 led to a fourfold overproduction of STE12 (see below) and an increased expression of several pheromone-inducible genes. A FUS1lacZ gene was used to measure FUS1 transcription, which has been shown to be strictly dependent on the presence of wild-type STE7, STE11, and STE12 products and to be highly inducible by pheromone (McCaffrey et al. 1987; Trueheart et al. 1987). The FUS1-lacZ gene was introduced on plasmid pSB231; this plasmid will be designated FUS1-lacZ. a $S T E^{+}$cells carrying FUS1lac $Z$ produced $\sim 0.1$ units of $\beta$-galactosidase activity in the absence of pheromone and 25-30 units in the presence of $\alpha$-factor (Table 2). Mutant ste strains carrying this plasmid showed no detectable $\beta$-galactosidase activity in the absence or presence of $\alpha$-factor (Table 2).

a $S T E^{+}$cells carrying both FUS1-lacZ and $2 \mu$-STE12 produced an average of 5-10 units of $\beta$-galactosidase activity, an increase $>50$-fold relative to a $S T E^{+}$cells not carrying $2 \mu$-STE12. However, on treatment with $\alpha$ factor, these double transformants produced essentially the same activity as that seen in $\alpha$-factor-treated cells lacking $2 \mu$-STE12 (Table 2). Mutant strains carrying both FUS1-lacZ and $2 \mu$-STE12 showed an increase in uninduced expression comparable to that seen in the $S T E^{+}$strain (0.7-7 units). However, unlike the $S T E^{+}$ strain, the mutant strains failed to induce higher levels of FUS1- $\beta$-galactosidase in response to $\alpha$-factor (Table 2). These results indicate that the amount of STE12 produced from a multicopy plasmid is capable of increasing uninduced transcription, regardless of the presence of ste 7 or ste11 mutations. However, it is not sufficient to overcome the lack of responsiveness of these mutants to pheromone. Furthermore, in the $S T E^{+}$background, this level of STE12 does not lead to an increased $\alpha$-factor-in- 
Table 1. Yeast strains

\begin{tabular}{|c|c|c|}
\hline Strain & Genotype & Source \\
\hline EG123 & MATa $S T E^{+}$can1 his4 leu2 trp1 ura3 & Siliciano and Tatchell (1984) \\
\hline SF167-5a & EG123 ste $12::$ LEU2 & Fields and Herskowitz (1987) \\
\hline DC129 & EG123 ste $7 \Delta 1$ & Fields et al. (1988) \\
\hline DC40 & EG123 ste $11 \Delta 1$ & Chaleff and Tatchell (1985) \\
\hline YY709 & EG123 ste $7 \Delta$ ste $11 \Delta$ & Fields et al. (1988) \\
\hline 438 & EG123 ste2 :: TRP1 & B. Hoopes \\
\hline $246-1-1$ & MAT $\alpha$ STE + can1 his4 leu2 trp1 ura3 & Siliciano and Tatchell (1984) \\
\hline SF167-lc & 246-1-1 ste12 :: LEU2 & Fields and Herskowitz (1987) \\
\hline DC130 & $246-1-1$ ste $7 \Delta 1$ & Fields et al. (1988) \\
\hline DC39 & 246-1-1 ste $11 \Delta 1$ & Chaleff and Tatchell (1985) \\
\hline YY408 & $246-1-1$ ste $7 \Delta$ ste $11 \Delta$ & Fields et al. (1988) \\
\hline EMPY11 & $\begin{array}{l}M A T \alpha G A L^{+} S T E^{+} \text {ade2-101 his } 3 \Delta 200 \\
\text { lys2-801 suc2 ura3-52 }\end{array}$ & E. Phizicky \\
\hline W303-1A & $\begin{array}{l}\text { MATa } G A L^{+} S T E^{+} \text {ade2-1 can1-101 } \\
\text { his3-11,15 leu2-3,112 trp1-1 ura3 }\end{array}$ & R. Rothstein \\
\hline $227 \mathbf{a}$ & MATa cry1 lys 1 & I. Herskowitz \\
\hline $\operatorname{AM} 227 \alpha$ & $M A T \alpha$ lys 1 & A. Mitchell \\
\hline RC631 & $\begin{array}{l}\text { MATa sst2-1 ade2 can1 cyh2 his } 6 \\
\text { met1 rme1 ura3 }\end{array}$ & Chan and Otte (1982) \\
\hline $\mathrm{RC} 757$ & MAT $\alpha$ sst2-1 can 1 cyh2 his 6 met 1 & Chan and Otte (1982) \\
\hline
\end{tabular}

duced level of transcription, indicating that the level of STE12 is not limiting after pheromone induction.

We assayed the effect of STE12 overproduction on expression of the a-factor genes by means of a halo assay (Wilson and Herskowitz 1984). The amount of a-factor produced is visualized by a zone of growth inhibition in a lawn of $\alpha$ cells carrying an sst 2 mutation /Chan and Otte 1982), which makes them supersensitive to afactor. As seen in Figure 1a, a $S T E^{+}$cells produced a large, well-defined a-factor halo, whereas the ste7, ste11, and ste 7 ste 11 mutant cells produced a halo that was barely detectable. The presence of $2 \mu$-STE 12 in the STE ${ }^{+}$ cells increased the size of the halo, consistent with an increased level of transcription of $M F A 1$ and/or MFA2.

Table 2. $\beta$-Galactosidase activity of a cells containing plasmids that carry the FUS1-lacZ gene and the STE12 gene

\begin{tabular}{|c|c|c|c|}
\hline Strain $^{a}$ & Plasmid $^{\mathbf{b}}$ & $\begin{array}{l}-\alpha- \\
\text { Factor }^{\mathrm{c}}\end{array}$ & $\begin{array}{l}+\alpha- \\
\text { Factor }\end{array}$ \\
\hline$S T E^{+}$ & FUSI-lacZ & 0.1 & 30.1 \\
\hline ste7 & FUS1-lacZ & 0 & 0 \\
\hline ste11 & FUS1-lacZ & 0 & 0 \\
\hline ste7,ste11 & FUS1-lacZ & 0 & 0 \\
\hline$S T E^{+}$ & $\begin{array}{l}\text { FUS1-lacZ } \\
2 \mu \text {-STE12 }\end{array}$ & 6.8 & 23.3 \\
\hline ste7 & $\begin{array}{l}\text { FUS1-lacZ } \\
2 \mu \text {-STE12 }\end{array}$ & 0.7 & 0.8 \\
\hline ste11 & $\begin{array}{l}\text { FUS1-lacZ } \\
2 \mu \text {-STE12 }\end{array}$ & 6.6 & 7.6 \\
\hline ste7,ste11 & $\begin{array}{l}\text { FUS1-lacZ } \\
2 \mu \text {-STE12 }\end{array}$ & 3.8 & 4.2 \\
\hline
\end{tabular}

${ }^{a} S_{E}{ }^{+}$strain is EG123 and ste strains are EG123 derivatives. bFUS1-lacZ is plasmid pSB231 and $2 \mu$-STE12 is plasmid pSY2. ' $\beta$-Galactosidase assays were performed on whole cells as described in Experimental procedures. Numbers represent Miller units and are the average of at least three independent assays.
The presence of this plasmid also resulted in a substantial increase in the size of the halo produced by the ste cells, to a level almost as large as that produced by the $S T E^{+}$strain with a control plasmid. As observed with FUS1 transcription, the effect of STE12 overproduction on expression of the a-factor genes is least dramatic in the ste 7 mutant. However, the a ste 7 mutant in this assay contained the plasmid pSY1, from which $\mathrm{pSY} 2$ was derived. pSYl contains a duplication of vector sequences that appears to stimulate plasmid instability and may partially account for the smaller halo associated with this strain. $\alpha$ Cells carrying $2 \mu$-STE1 2 were assayed for $\alpha$-factor production by use of a lawn of a sst2 cells. As with a cells, the presence of $2 \mu$-STE12 restored the ability of the $\alpha$ ste cells to produce pheromone at a level comparable to wild type (Fig. 1b).

The level of BAR1 expression was also measured in cells containing and lacking $2 \mu$-STE12. The barrier function, encoded by $B A R 1$, is secreted by a cells to degrade $\alpha$-factor (Sprague and Herskowitz 1981). Barrier activity was very low or absent in the ste mutants, but on introduction of $2 \mu$-STE12, these mutants secreted barrier at a level approaching that seen with $S T E^{+}$cells (data not shown).

Overproduction of STE12 suppresses ste2, ste7, and stell mating defects

Although the presence of $2 \mu$-STE12 was insufficient to allow $\alpha$-factor induction in ste 7 and ste 11 mutants, it was capable of partially restoring mating ability to these strains. We demonstrated this suppression in two assays of mating ability. As shown in Figure 2, the mutants transformed with the vector YEp13 produced no diploids when replica-plated to a lawn of $S T E^{+}$cells of the opposite mating type. However, the presence of plasmid $2 \mu$ - 
a

\section{Vector $2 \mu$-STE12}

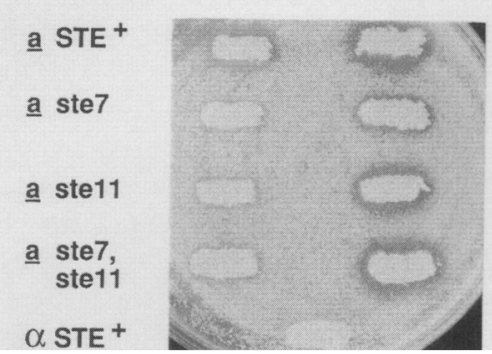

b

\section{$2 \mu$-STE12 Vector}

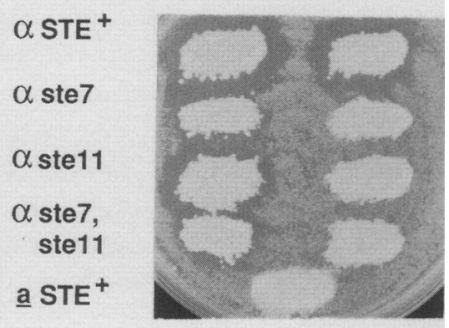

Figure 1. Halo assays for a-factor and $\alpha$-factor. $(a)$ The patches are strains being tested for a-factor production, with the lawn being an $\alpha$ sst2 mutant. (Left) Strains carrying the vector YEp13; (right) strains carrying the STE12 overproducing plasmid pSY2. The $\alpha$ STE ${ }^{+}$ strain carries YEp13. Secretion of a-factor prevents growth of the lawn and produces a clear zone around the source of a-factor. $(b)$ Strains being tested for $\alpha$-factor; the lawn is an a sst 2 mutant. The vector and $2 \mu$-STE12 plasmids are as in $a$; the a STE ${ }^{+}$strain carries YEp13.

STE12 restored the ability of the mutants to mate, albeit at a very low level relative to $S T E^{+}$cells. This overproduction of STE12 was able to suppress the mating defect caused by the ste mutations in both a and $\alpha$ backgrounds (Fig. 2). Double mutants containing both ste mutations

\section{a}
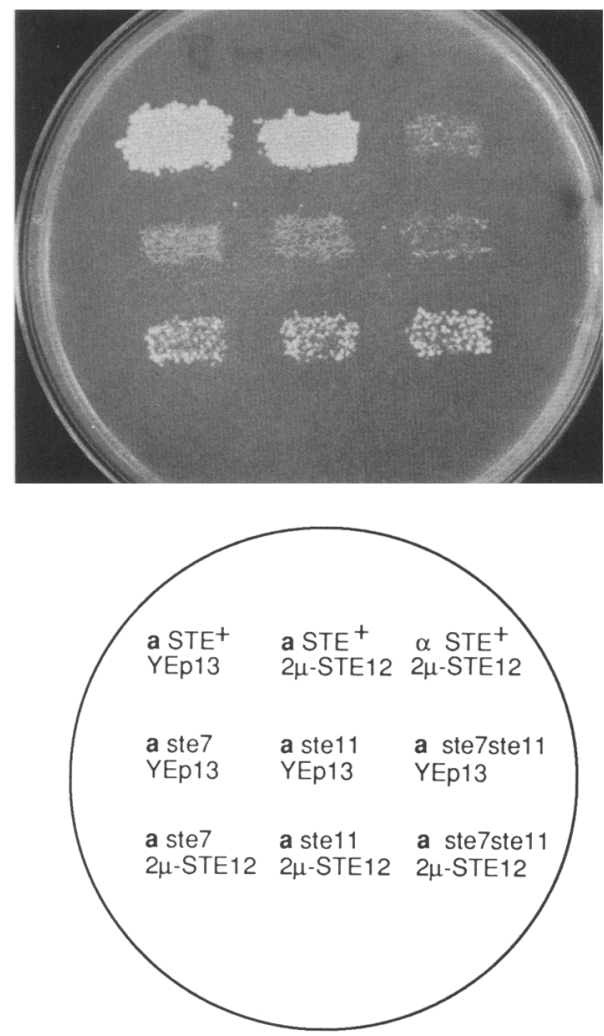

appeared to be suppressed as well as either single mutant (Fig. 2).

A quantitative assay was also used to determine the mating ability of these strains, as well as that of an a ste2 mutant. The STE2 gene encodes the $\alpha$-factor re-

b
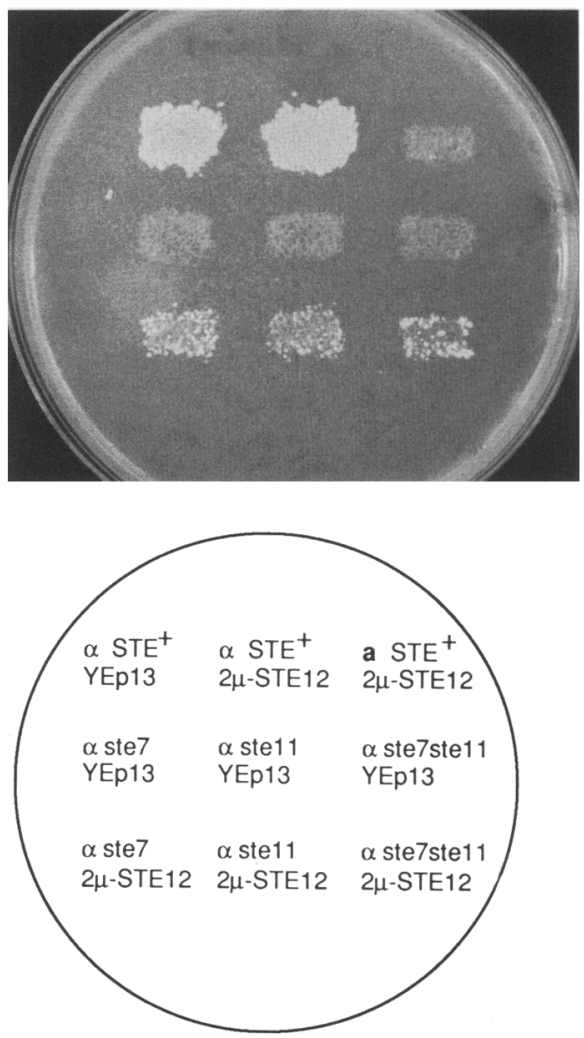

Figure 2. Mating assays of strains overproducing STE12. (a) A plate assay testing patches of strains for their ability to mate as a cells, with strain and plasmid designations indicated below it. The test strains have been replica-plated from an SD-leucine plate onto an SD-minimal plate spread with a lawn of an $\alpha S T E^{+}$strain. $|b|$ A similar experiment testing the ability of strains to mate as $\alpha$ cells with an a $S T E^{+}$lawn. The $2 \mu$-STE12 in these transformants is pSY1. 
ceptor (Burkholder and Hartwell 1985; Nakayama et al. 1985; Blumer et al. 1988), so that ste2 mutants are also completely unresponsive to pheromone. However, the ste2 mutation, unlike ste7, ste11, or ste12 mutations, does not affect the level of uninduced cell-type-specific expression (Hartwell 1980). The ste mutants without a plasmid produced no diploids $\left(\left\langle 10^{-7}\right)\right.$, whereas the ste 7 and ste 11 mutants carrying $2 \mu$-STE 12 (plasmid pSY2) mated at an average frequency of $5 \times 10^{-5}$, an increase of at least 500 -fold (Table 3). The ste2 mutant was suppressed at a lower level (Table 3). The mating results of the ste mutants carrying $2 \mu$-STE 12 , combined with the inability of the ste 7 and ste11 strains with this plasmid to induce FUS1-lacZ expression in response to $\alpha$-factor, indicate that yeast can mate, although at much reduced efficiency, apparently without the pheromone response pathway operating. Presumably, the increased level of transcription from pheromone-inducible genes, mediated by the overproduced STE12, is capable of allowing a small percentage of the cells in the population to carry out the mating process.

We also tested the ability of the a ste mutants carrying $\mathrm{P}_{\mathrm{GAL}} \mathrm{STE} 12$ to mate. Gel mobility-shift assays indicated that this plasmid caused an approximate eightfold overproduction of STE12 in these strains (data not shown). Cells were grown in raffinose medium, shifted to $5 \%$ galactose for $8 \mathrm{hr}$, mixed with an $\alpha S T E^{+}$strain in YEP galactose for $4 \mathrm{hr}$, and then plated for diploids. Efficiency of mating for the ste 7 and ste11 strains averaged $8 \times 10^{-4}$, and for the ste2 strain, $1.5 \times 10^{-5}$ (Table 3). These frequencies were $\sim 10$-fold greater than those of strains containing $2 \mu$-STE12, even though $S T E^{+}$cells subjected to this same galactose regimen mated 10 -fold less efficiently than $S T E^{+}$cells in glucose.

We assayed whether overproduction of other STE products, the STE7 and STE11 proteins, could suppress

Table 3. Quantitative mating efficiency of strains that overproduce STE12

\begin{tabular}{|c|c|c|c|}
\hline Strain $^{a}$ & Plasmid & $\begin{array}{l}\text { Carbon } \\
\text { source }\end{array}$ & $\begin{array}{l}\text { Mating } \\
\text { efficiency }\end{array}$ \\
\hline$S T E^{+}$ & $2 \mu$-STE 12 & glucose & $2.3 \times 10^{-1}$ \\
\hline ste2 & $\begin{array}{l}2 \mu \text {-STE } 12 \\
\text { no plasmid }\end{array}$ & glucose & $\begin{array}{r}2.9 \times 10^{-6} \\
<1.0 \times 10^{-7}\end{array}$ \\
\hline ste7 & $\begin{array}{l}2 \mu \text {-STE12 } \\
\text { no plasmid }\end{array}$ & glucose & $\begin{array}{r}3.9 \times 10^{-5} \\
<1.0 \times 10^{-7}\end{array}$ \\
\hline ste11 & $\begin{array}{l}2 \mu \text {-STE12 } \\
\text { no plasmid }\end{array}$ & glucose & $\begin{array}{r}4.7 \times 10^{-5} \\
<1.0 \times 10^{-7}\end{array}$ \\
\hline ste7,ste11 & $\begin{array}{l}2 \mu \text {-STE12 } \\
\text { no plasmid }\end{array}$ & glucose & $\begin{array}{r}4.2 \times 10^{-5} \\
<1.0 \times 10^{-7}\end{array}$ \\
\hline$S T E^{+}$ & $\mathrm{P}_{\mathrm{GAL}} \mathrm{STE} 12$ & galactose & $2.3 \times 10^{-2}$ \\
\hline ste2 & $\mathrm{P}_{\mathrm{GAL}} \mathrm{STE} 12$ & $\begin{array}{l}\text { raffinose } \\
\text { galactose }\end{array}$ & $\begin{array}{r}<1.0 \times 10^{-7} \\
1.5 \times 10^{-5}\end{array}$ \\
\hline ste7 & $\mathrm{P}_{\mathrm{GAL}} \mathrm{STE} 12$ & $\begin{array}{l}\text { raffinose } \\
\text { galactose }\end{array}$ & $\begin{array}{r}<1.0 \times 10^{-7} \\
4.8 \times 10^{-4}\end{array}$ \\
\hline ste11 & $\mathrm{P}_{\mathrm{GAL}} \mathrm{STE} 12$ & $\begin{array}{l}\text { raffinose } \\
\text { galactose }\end{array}$ & $\begin{array}{r}<1.0 \times 10^{-7} \\
1.5 \times 10^{-3}\end{array}$ \\
\hline ste7,ste11 & $\mathrm{P}_{\mathrm{GAL}} \mathrm{STE} 12$ & $\begin{array}{l}\text { raffinose } \\
\text { galactose }\end{array}$ & $\begin{array}{r}<1.0 \times 10^{-7} \\
4.0 \times 10^{-4}\end{array}$ \\
\hline
\end{tabular}

aStrains as in Table 2. mating defects of the appropriate ste mutants. Transformation with plasmid pID7, a multicopy plasmid carrying the STE7 gene, could complement a ste 7 mutation, but it did not lead to suppression of either ste11 or ste12 mutants (data not shown). Similarly, plasmid pJD11, carrying the STE11 gene on a multicopy plasmid, could complement a ste11 mutation but did not lead to diploids when present in ste7 or ste12 strains /data not shown). These results suggest, first, that the STE7 and STE11 products are acting before the STE12 product in the response pathway: Overproduction of the two presumed protein kinases cannot suppress the requirement for the transcription factor bound to the PRE. Second, the inability of a high copy plasmid carrying STE7 to suppress a ste11 mutation, and vice versa, suggests that these two proteins may not have overlapping functions or specificity. The failure of a STE7 plasmid to complement a ste11 mutation and a STE11 plasmid to complement a ste7 mutation had been noted previously by Chaleff and Tatchell 1985.)

STE 12 expression is relatively unaffected by the ste 7 and stell mutations

One possible explanation for the incomplete suppression of ste 7 and ste 11 mutants carrying $2 \mu$-STE 12 is that the expression of the STE12 gene is absolutely dependent on the products of the STE7 and STE11 genes. In this case, the level of STE12 protein in the transformed mutants would still be lower than in the $S T E^{+}$strain. To investigate this possibility, we prepared extracts from $S T E^{+}$ and ste 7 and ste11 strains, both containing and lacking $2 \mu$-STE12. These extracts were used in gel mobility assays with a fragment from the $M F A 2$ gene as probe (Fig. 3, lane 1). This probe can produce the two STE12bound shifted bands, indicated by arrows (cf. lanes 2 and 7). In strains not carrying $2 \mu$-STE12 (lanes 3-6), the level of STE12 DNA binding activity was not dramatically different between $S T E^{+}$and ste 7 or ste11 backgrounds. In general, this activity was reduced two- to threefold in the ste 7 and ste11 strains relative to wild type; this reduction varied somewhat from extract to extract.

The presence of $2 \mu$-STE 12 resulted in an approximate fourfold increase in STE12 DNA binding activity in both $S T E^{+}$and mutant strains (Fig. 3, lanes 7-10). The level of activity in the mutants was in excess of the level seen in the $S T E^{+}$strain lacking the plasmid (cf. lane 3 with lanes $8-10$ ). Therefore, the inability of ste 7 and ste11 strains carrying either $2 \mu$-STE 12 or $\mathrm{P}_{\mathrm{GAL}}$ STE 12 to mate with wild-type efficiency is not due to an insufficient amount of STE12 being produced.

\section{STE12 produced from a galactose-inducible promoter causes lethality}

Although cells are able to tolerate the continuous expression of STE12 from a multicopy plasmid, they show a more extreme phenotype when expressing this protein from the galactose-inducible promoter. The level of 


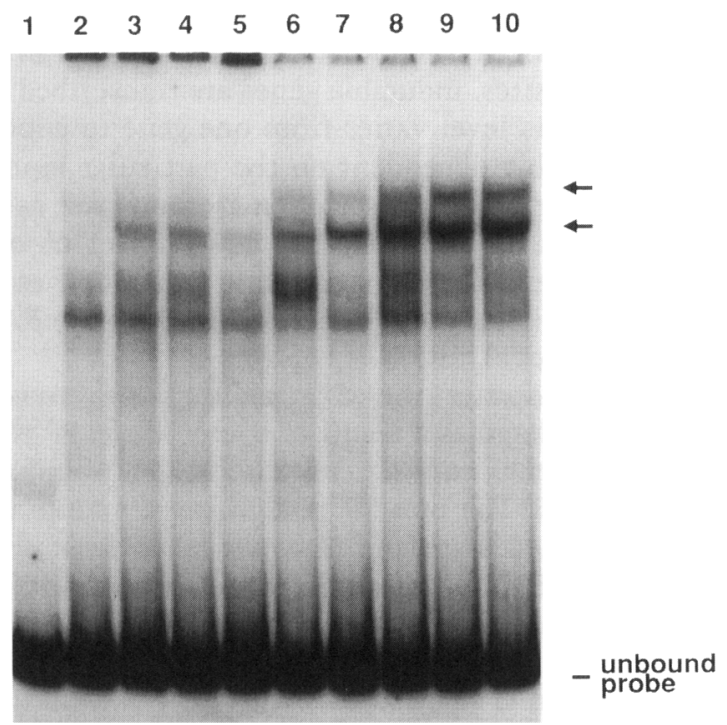

Figure 3. Gel mobility-shift assay to detect STE12 DNAbinding activity. Extracts are from the following strains: $|1\rangle$ No extract; (2) a ste12; (3) a $S T E^{+} ;$(4) a ste 7; (5) a ste11; (6) a ste 7 ste 11 ; (7) a STE $+2 \mu$-STE12; (8) a ste7 $2 \mu$-STE12; (9) a ste11 $2 \mu$ STE12; $(10)$ a ste 7 ste $112 \mu$-STE12. The probe was a fragment of the MFA2 gene containing two PRE sequences. Arrows indicate the position of the STE12-dependent DNA-protein complexes. The $2 \mu$-STE 12 was plasmid pSY2.

STE12 in the $S T E E^{+} G A L^{+}(\mathrm{W} 303-1 \mathrm{~A})$ cells containing the galactose-inducible STE12 gene on plasmid $\mathrm{P}_{\mathrm{GAL}} \mathrm{STE} 12$ was $\sim 20$-fold higher in galactose as compared to raffinose, which does not induce the GAL1,10 promoter (data not shown). W303-1A containing either $\mathrm{P}_{\mathrm{GAL}} \mathrm{STE} 12$ or the parental vector was grown in raffinose-containing medium and then shifted to galactose. Cells containing the vector PBM150 continued to grow normally in galactose (Fig. 4a), as did cells containing $\mathrm{P}_{\mathrm{GAL}} \mathrm{STE} 12$ maintained in raffinose (Fig. $4 \mathrm{~b}$ ). However, after $8 \mathrm{hr}$ in galactose for the culture containing $\mathrm{P}_{\mathrm{GAI}} \mathrm{STE} 12$, most of the cells in the population exhibited some morphological changes, and only $20 \%$ of the cells showed the appearance of normal buds (Fig. 4c,d). Many cells were larger than control cells, had elongated regions or, in some cases, had two large buds. In addition, some of the cells contained long, thin projections.

The morphological changes associated with galactose induction suggested that many cells carrying $\mathrm{P}_{\mathrm{GAL}} \mathrm{STE} 12$ were arresting in the $\mathrm{G}_{1}$ phase of the cell cycle. To assay directly for $G_{1}$ arrest, we analyzed cultures for their percentage of unbudded cells (Fig. 5a). Cultures containing the parental vector pBM150, grown in raffinose or shifted to galactose, showed an average of $\sim 40 \%$ unbudded cells, as did cultures containing $\mathrm{P}_{\mathrm{GAL}} \mathrm{STE} 12$ grown in raffinose. When shifted to galactose, the culture containing $\mathrm{P}_{\mathrm{GAL}} \mathrm{STE} 12$ began to increase its percentage of unbudded cells, reaching a maximum of $70-80 \%$ after $6 \mathrm{hr}$ in galactose, an indication that some $\mathrm{G}_{1}$ arrest was occurring. This percentage did not reach $100 \%$, as it does for $\alpha$-factor treatment, nor did the mor- phology of the cells overproducing STE 12 resemble classical shmoos. Thus, although cells constitutively producing high levels of pheromone-inducible products showed some similarities to those treated with pheromone, they did not perfectly mimic all aspects of pheromone response.

When cells carrying $P_{\mathrm{GAL}} \mathrm{STE} 12$ were inoculated onto a galactose plate that required maintenance of the plasmid marker (URA3), they failed to produce colonies (Fig. 5b), indicating that a very high level of STE12 is lethal. These cells did double a number of times, as evidenced by growth in the thickest part of the inoculum, presumably reflecting the need to build up sufficient levels of STE12 to cause a lethal phenotype. This lethality may be a consequence of cell-cycle arrest or may be due to the toxic buildup of other pheromone-induced proteins.

\section{Discussion}

The yeast STE12 protein binds to the PRE located in the regulatory region of inducible genes whose products are involved in the mating process. STE 12 has been overexpressed by means of a multicopy plasmid and a galactose-inducible promoter, and the effects of this overproduction have been assayed in both $\mathrm{STE}^{+}$and ste2, ste7, or ste11 backgrounds. We find that overproduction of STE12 results in greater than wild-type levels of celltype-specific products in a $S T E^{+}$strain and increases the low level of these products found in ste7 and ste11 strains to nearly wild-type levels. These results suggest

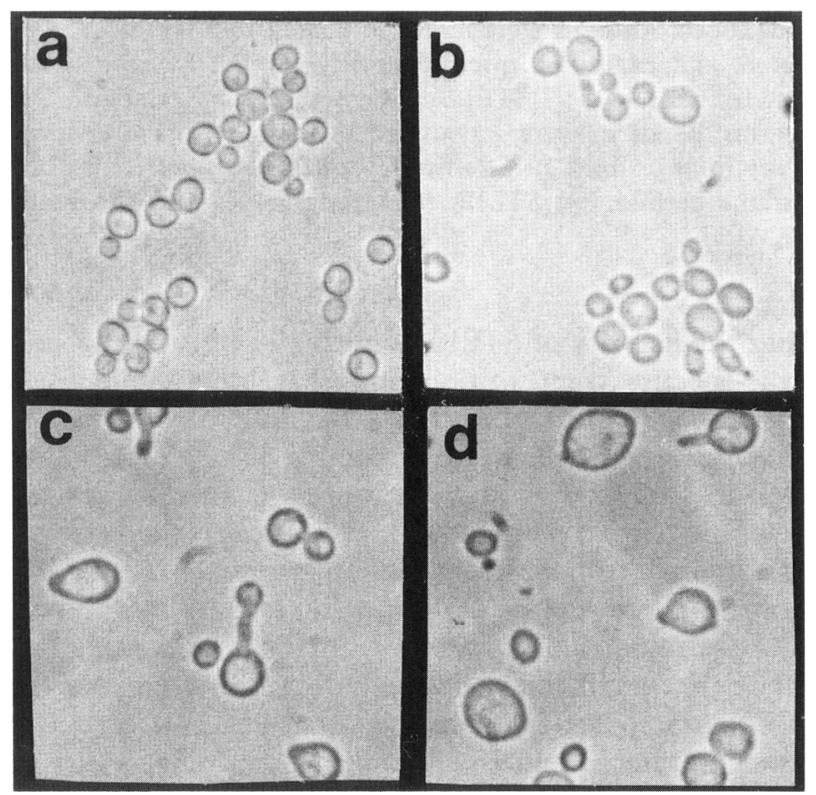

Figure 4. Morphology of cells overproducing STE12 from a galactose-inducible promoter. The strain in all panels is W303-1a, a $G A L^{+} S T E^{+}$. (a) $\mathrm{P}_{\mathrm{GAL}} \mathrm{STE} 12$ transformant grown in raffinose; (b) vector pBM150 transformant grown in galactose; ( $c$ and $d$ ) two independent cultures of a $\mathrm{P}_{\mathrm{GAL}} \mathrm{STE} 12$ transformant after shift to galactose for $8 \mathrm{hr}$. 

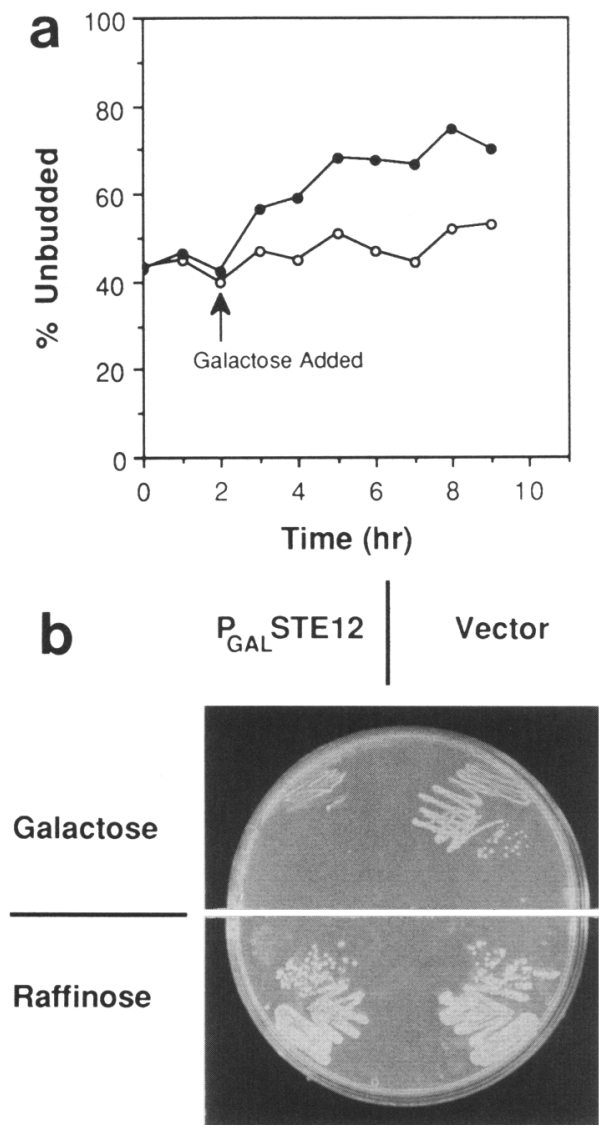

Figure 5. (a) STE12 overproduced from a galactose-inducible promoter causes the accumulation of unbudded cells. Cultures of an a $G A L^{+} S T E^{+}$strain containing the vector $\mathrm{pBM} 150(O)$ or $\mathrm{P}_{\mathrm{GAL}} \mathrm{STE} 12$ (O) were grown in raffinose, and at $2 \mathrm{hr}$, galactose was added. Aliquots were removed at the times indicated, sonicated, and examined microscopically for the fraction of unbudded cells. $(b) \mathrm{P}_{\mathrm{GAL}} \mathrm{STE} 12$ causes lethality on galactose. The strains, as in $a$, were inoculated onto an S-galactose-uracil plate (top) or onto an S-raffinose-uracil plate (bottom). (Left) Strains carried $\mathrm{P}_{\mathrm{GAL}} \mathrm{STE} 12$; (right) strains carried the vector pBM150.

that the activity of STE 12 is normally limiting for celltype-specific transcription and that pheromone treatment leads to transcriptional induction by increasing the activity of STE12. The effect of STE12 overproduction in ste2, ste7, and ste11 strains is that the mating defect is partially suppressed, even though these strains are unable to respond to pheromone. However, the mating efficiency is dramatically lower than that of $S T E^{+}$strains, indicating that the pheromone-induced signal has additional effects that can only be partially compensated for by increased transcription of pheromone-inducible genes.

\section{Model of STE12 function}

STE12 is a DNA-binding transcriptional activator that mediates pheromone induction by binding to the PRE present in inducible genes. The bound protein coop- erates with other transcription factors to produce the observed levels of expression. In the absence of STE12 or STE12-binding sites, inducible genes are transcribed at a lower level. This level varies from one gene to another and is presumably dependent on the particular binding sites present for other transcription factors, such as the MCM1 product. In addition, this lower level of transcription is insensitive to pheromone treatment, as observed by deletion of the PRE sequences from the BAR1 gene (Kronstad et al. 1987).

Figure 6 illustrates the changes that we envision STE12 may undergo as a result of overproduction, pheromone treatment, and ste mutations. In uninduced $S T E^{+}$cells, STE12 is present in limiting amounts in a partially modified state and is bound to at least some PREs. That STE12 is present in limiting quantities is supported by the fact that overproduction of STE12 results in increased levels of uninduced transcription. Partial modification is suggested by the effect of mutations on the level of STE12-dependent transcription in uninduced cells. Mutations that eliminate components of the pheromone response pathway, such as ste4, ste5, ste7, or ste11, affect transcription of responsive genes to the same extent as mutations in STE12 (Hartig et al. 1986; Fields et al. 1988), which eliminate the transcription factor. The effect of these mutations also resembles that of mutations that eliminate PREs in responsive genes (Kronstad et al. 1987). The fact that pathway mutations can affect the uninduced activity of STE12 supports the idea of partial modification by a low-level constitutive signal through the response pathway. Partial modification may take either of two forms: All molecules of STE 12 are partially modified or a fraction of the molecules are fully modified. The nature of the modification dependent on the pheromone response pathway is unknown; it could include post-translational modification of the STE12 protein itself (e.g., phosphorylation), changes in the stability of STE12, binding of STE12 to another activator, or dissociation of STE12 from a repressor. For simplicity in this discussion, we assume that STE12, itself, is the target for a post-translational modification.

In response to pheromone, the a- and $\alpha$-specific and certain haploid-specific genes are transcribed at higher levels. We suggest that this transcriptional induction is mediated by more complete modification of STE12, based on the results reported here and the following reasons. First, the induction is rapid and occurs in the presence of cycloheximide (Hagen and Sprague 1984). Second, we have found that a hybrid protein composed of the GAL4 DNA-binding domain and all of STE12 is able to drive transcription from GAL4-binding sites but only after treatment of the cells with pheromone $(O$. Song and S. Fields, unpubl.). In addition to this rapid response, pheromone treatment also leads to increased STE12 transcription (J.W. Dolan and S. Fields, unpubl.). Thus, maximum transcriptional activation occurs because sufficient STE12 is synthesized and is modified to its fully active form. In ste7 and ste 11 cells, pheromone treatment has no effect on the ability of STE12 to acti- 


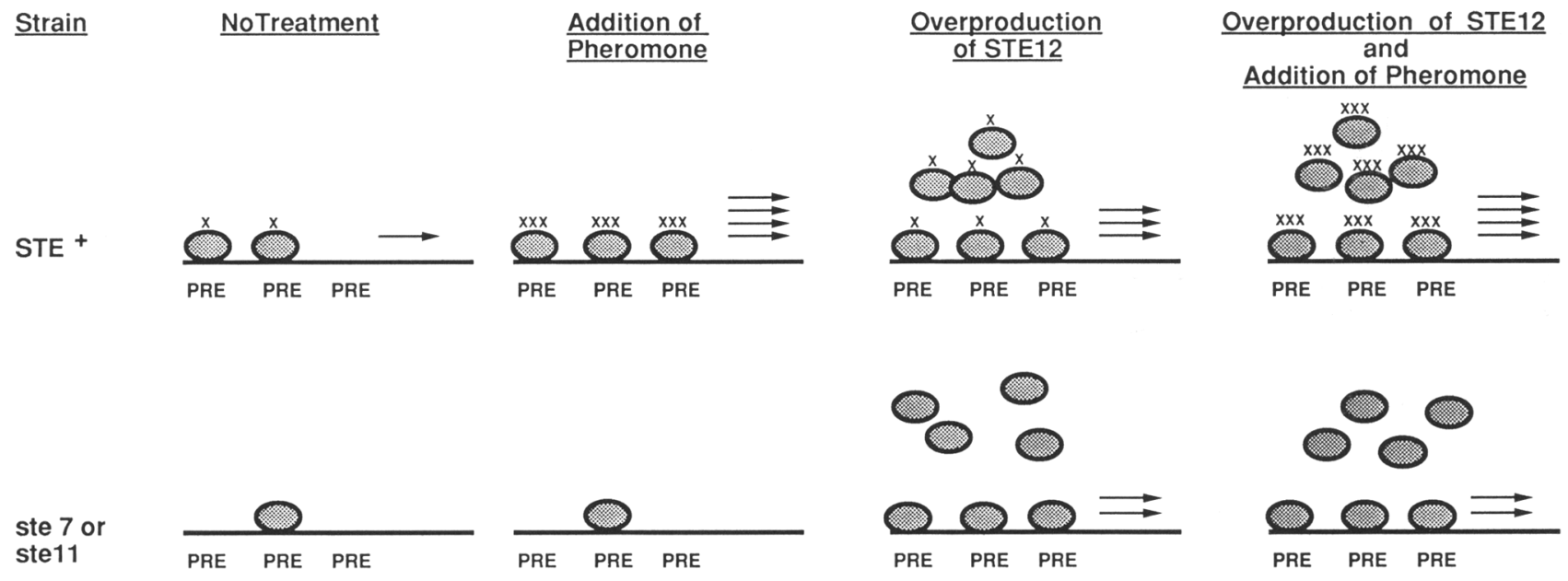

Figure 6. Model of STE12 function. Shaded ovals represent STE12 proteins, X represents a modification dependent on the pheromone response pathway, and the number of arrows indicates the qualitative level of transcription of a pheromone-responsive gene.

vate transcription because the response pathway is not functional.

Overproduction of STE12 in STE ${ }^{+}$or ste cells results in higher levels of transcription from inducible genes. Thus, the level of STE12 provided by the single chromosomal copy of the STE12 gene in the ste7 and ste $11 \mathrm{mu}-$ tants is not sufficient for wild-type, uninduced expression of responsive genes, probably due to the loss of STE12 modification provided by the pheromone response pathway. However, uninduced levels of expression comparable to those seen in $S T E^{+}$strains can be attained in the ste 7 and ste11 mutants by overproduction of STE12; the overproduced STE12 may not be an effective transcriptional activator due to the lack of modification but can activate transcription by mass-action effects. A small percentage of the overproduced STE12 may also be fortuitously modified, and thus partially activated, by proteins that are not dependent on the pheromone response pathway.

Overproduction of STE12 in STE ${ }^{+}$cells does not result in increased $\alpha$-factor-induced transcription of FUS1. The failure to observe such an enhancement suggests either that another transcription component becomes limiting under inducing conditions or that an activity that modifies STE12 in response to pheromone becomes limiting. In the second case, only the wild-type level of STE12 becomes modified, whereas the excess that results from overproduction does not. Treatment of ste 7 or ste11 cells overproducing STE12 with pheromone does not result in induced transcription: Only the enhanced level of uninduced transcription due to overproduction is seen. The addition of pheromone to these mutants overproducing STE12 has no effect on transcription from FUS1 because the ste mutations block the signal generated by pheromone.

\section{Pheromone response pathway}

Overproduction of STE12 caused by galactose-inducible STE12 transcription leads to additional phenotypes.
Many cells arrest in $\mathrm{G}_{1}$, as evidenced by an increasing percentage of unbudded cells and, with time, form cellsurface projections. Although these cells do not exactly mimic pheromone-treated cells, their large size, arrested state, and projections bear certain similarities to cells responding to pheromone. These results suggest that some pheromone-inducible proteins may be interacting with constitutively present $C D C$ (cell-division cycle) or $C L N$ (cyclin) products as part of the $\mathrm{G}_{1}$ arrest response. A candidate protein that is induced by pheromone and that may interact with cell-cycle components is the FAR1 product (F. Chang and I. Herskowitz, pers. comm.); far1 mutants induce transcription and shmoo but continue to divide in the presence of $\alpha$-factor. The involvement of cyclins is indicated by the isolation of mutations in the CLN3 gene (DAF1-1 of Cross 1988 and WHI1-1 of Nash et al. 1988) that cause $\alpha$-factor resistance and a reduced $G_{1}$ phase of the cell cycle. Other pheromone-induced proteins may interact with constitutive proteins necessary for nuclear modification and projection formation. In addition, overproduction of STE12 may lead to a higher level of other pheromone-inducible components of the signal response pathway, itself, and these pathway components may contribute to certain aspects of pheromone response.

Any model of the response pathway must also account for the relatively inefficient mating of the ste mutants when overproducing STE12. It is clear that pheromone binding leads to responses that overproduction of STE12 does not. For example, an a cell apparently senses the nearby presence of an $\alpha$ cell and forms a mating projection directed toward the potential mating partner, whereas a cells suspended in medium containing $\alpha$ factor form projections in random directions (Cross et al. 1988). Thus, cells that are forming projections that result from high levels of STE12 would not follow any directional constraints, resulting in reduced mating efficiency. In addition, pheromone treatment also leads to events initiating recovery from cell-cycle arrest. Cells overproducing STE12 and continuing to produce high 
levels of pheromone-inducible products may be incapable of recovering properly from their effects.

The ability of STE12 overproduction to cause constitutively high levels of cell-type-specific products suggests that this protein, itself, is a target of the pheromone-induced signal. It will therefore be of interest to determine the biochemical mechanism by which STE12 becomes activated.

\section{Experimental procedures}

Yeast strains

The strains of S. cerevisiae used are listed in Table 1.

\section{Plasmids}

The STE12 gene was cloned into the vector YEpl3 to yield the plasmid pSY1 (Dolan et al. 1989). An SphI fragment that contained duplicated vector sequences was deleted to yield pSY2. The STE12 gene was also cloned into the EcoRI site of pBMI50 (Johnston and Davis 1984) as an EcoRI fragment beginning at the initiator ATG of the STE12 gene to yield $\mathrm{P}_{\mathrm{GAL}}$ STE12. The FUS1-lacZ fusion carried on pSB231 was obtained from J. Trueheart; the lac $Z$ fusion is described in Trueheart et al. (1987) and pSB231 is a CEN4, URA3 plasmid. Plasmid pID7 was constructed by moving the STE7 gene as a HindIII fragment from pSTE7 (Chaleff and Tatchell 1985) into the HindIII site of pBluescript II (Stratagene). The STE7 gene was then moved as a BamHI-SalI fragment into YEp24 (Botstein et al. 1979). Plasmid pID11 was constructed by moving the STE11 gene as a BamHI-Sall fragment from pSTE1 (Chaleff and Tatchell 1985) directly into YEp24.

\section{Media and yeast transformation}

Media used were YEP and synthetic (S) (Sherman et al. 1986). Carbon sources used were glucose (SD and YEPD), raffinose (SRaf and YEP-Raf), and galactose (SGal and YEP-Gal). Synthetic media were used without supplements (e.g., SD-minimal) or supplemented with amino acids and nucleosides (Sherman et al. 1986). To maintain plasmids with selectable markers, the media were supplemented with all but the indicated component(s) (e.g., SD-uracil). Yeast transformations were done using the glusulase procedure (Beggs 1978) or the lithium chloride procedure (Ito et al. 1983).

\section{Mating assays}

A patch mating test was used as a qualitative measure of mating competence. Strains carrying either $2 \mu$-STE12 or YEP13 were inoculated onto SD-leucine plates and allowed to grow into a heavy patch, replica-plated onto a lawn of tester cells of the opposite mating type, either 227 a or AM227 $\alpha$, on SD-minimal medium, and incubated for 2-3 days to allow the growth of diploid colonies.

For quantitative mating tests, a strains carrying $2 \mu$-STE 12 or no plasmid were grown on SD-leucine or SD-complete medium, respectively, to a density of $1 \times 10^{7}$ to $5 \times 10^{7}$ cells $/ \mathrm{ml}$. Aliquots $(300 \mu l)$ were mixed with a 5- to 10 -fold excess of EMPYIl grown in YEPD. The mixtures were incubated at $30^{\circ} \mathrm{C}$ for $2 \mathrm{hr}$ and then plated on SD-minimal plates that had been supplemented with uracil. a strains carrying $\mathrm{P}_{\mathrm{GAL}} \mathrm{STE} 12$ were grown on SRaf-uracil to a density of $\sim 5 \times 10^{6}$ to $1 \times 10^{7}$ and then split into two aliquots. Galactose was added to $5 \%$ to one aliquot, and the cultures were incubated at $30^{\circ} \mathrm{C}$ for $8 \mathrm{hr}$ to induce STE12 expression. A 100- $\mu$ l aliquot was then mixed with an aliquot of EMPY11 grown in either YEP-Raf or YEP$\mathrm{Gal}$, as appropriate. The mixtures were incubated for $4 \mathrm{hr}$ and then plated on SD plates containing the required supplements.

Total numbers of cells per milliliter were determined by plating appropriately diluted aliquots of each parental strain on YEPD plates and counting colonies. The mating frequency is the number of diploids produced divided by the number of haploid a cells in the mating reaction.

\section{Extracts and gel mobility-shift assays}

Yeast extracts and gel mobility-shift assays were prepared as described previously (Dolan et al. 1989). For the galactose induction of $\mathrm{P}_{\mathrm{GAL}} \mathrm{STE} 12$-containing strains, the cells were grown in SRaf-uracil to an $\mathrm{OD}_{600}$ of 0.3 and galactose was added to a final concentration of $5 \%$. The cells were allowed to induce for $8 \mathrm{hr}$ before harvesting. The probe for the gel shift assay was the 209-bp EcoRI-HindIII fragment from pRR6 (Dolan et al. 1989) that contains upstream regulatory sequences from the MFA2 gene. This fragment was gel-purified and end-labeled using standard methods (Maniatis et al. 1982). Each gel mobility-shift reaction contained $20 \mu \mathrm{g}$ of protein, $0.5 \mathrm{ng}$ of probe, and $2 \mu \mathrm{g}$ of poly[d(I-C)]/poly[d(I-C)] in a total of $20 \mu \mathrm{l}$.

\section{$\beta$-Galactosidase assays}

Assays were performed as described (Miller 1972), except that cells were permeabilized by vortexing in $800 \mu \mathrm{l}$ of buffer $\mathrm{Z}$ with $50 \mu \mathrm{l}$ of chloroform and $20 \mu \mathrm{l}$ of $0.1 \%$ SDS. Following incubation with ONPG and quenching by sodium carbonate, the samples were centrifuged for $10 \mathrm{~min}$ to pellet cell debris. Activity was calculated as $\left[\mathrm{OD}_{420} \times 1000\right] /\left[\mathrm{OD}_{600} \times\right.$ time $(\mathrm{min})$ $\times V(\mathrm{ml})]$, where $V$ is the volume of culture used in the assay. Pheromone induction was measured by adding $\alpha$-factor (Sigma Chemicals) to a final concentration of $0.7 \mu \mathrm{M}$, after which the cultures were incubated for $90 \mathrm{~min}$ at $30^{\circ} \mathrm{C}$ prior to assay.

\section{Halo assays}

A patch of wild-type a cells will inhibit the growth of a lawn of $\alpha$ sst2-1 cells, producing a "halo" around the patch. The same effect is seen with patches of $\alpha$ cells on a lawn of a sst2-1 cells. Strains to be tested for pheromone production were patched onto a master plate containing the appropriate selective medium. After the patches had grown, they were replicated onto a lawn of sst2-1 cells on a YEPD plate. The plates were incubated overnight at $30^{\circ} \mathrm{C}$ and photographed.

\section{Budding assay}

Strains used were W303-1A, containing either $\mathrm{P}_{\mathrm{GAL}}$ STE12 or the vector (pBM150). Cells from an overnight culture grown in SRaf-uracil were used to inoculate fresh SRaf-uracil, and the cells were grown for $2 \mathrm{hr}$. At that time, galactose was added to a final concentration of $2 \%$. At 1 -hr intervals, aliquots were removed, sonicated for $20 \mathrm{sec}$, and the number of budded and unbudded cells were counted. Total cell counts for each time point numbered $\sim 200$.

\section{Microscopy}

Micrographs were taken with a Nikon Labophot using phase contrast. All micrographs were taken at $400 \times$ magnification; the galactose-induced $\mathrm{P}_{\mathrm{GAL}} \mathrm{STE} 12$ cells were sonicated briefly before spreading for photography. 


\section{Acknowledgments}

We thank Ira Herskowitz, George Sprague, and Rolf Sternglanz for comments on the manuscript. This work was supported by grant DMB-8601949/89164190 from the National Science Foundation and U.S. Public Health Service grant 5-T32CA09176 from the National Cancer Institute.

\section{References}

Beggs, J.D. 1978. Transformation of yeast by replicating hybrid plasmid. Nature 275: 104-109.

Bender, A., and G.F. Sprague, Jr. 1987. MAT $\alpha 1$ protein, a yeast transcription activator, binds synergistically with a second protein to a set of cell-type-specific genes. Cell 50: 681-691.

Blinder, D., S. Bouvier, and D.D. Jenness. 1989. Constitutive mutants in the yeast pheromone response: Ordered function of the gene products. Cell 56: 479-486.

Blumer, K.J., J.E. Reneke, and J. Thorner. 1988. The STE2 gene product is the ligand binding component of the a-factor receptor of Saccharomyces cerevisiae. I. Biol. Chem. 263: 10836-10842.

Botstein, D., S.C. Falco, S.E. Stewart, M. Brennan, S. Scherer, D.T. Stinchcomb, K. Struhl, and R.W. Davis. 1979. Sterile host yeasts (SHY): A eukaryotic system of biological containment for recombinant DNA experiments. Gene 8: $17-24$.

Burkholder, A.C. and L.H. Hartwell. 1985. The yeast $\alpha$-factor receptor: Structural properties deduced from the sequence of the STE2 gene. Nucleic Acids Res. 13: 8463-8475.

Chaleff, D.T. and K. Tatchell. 1985. Molecular cloning and characterization of the STE7 and STE11 genes of Saccharomyces cerevisiae. Mol. Cell Biol. 5: 1878-1886.

Chan, R.K. and C.A. Otte. 1982. Isolation and genetic analysis of Saccharomyces cerevisiae mutants super-sensitive to G1 arrest by a-factor and $\alpha$-factor pheromones. Mol. Cell Biol. 2: $11-20$.

Cross, F. 1988. DAF1, a mutant gene affecting size control, pheromone arrest, and cell cycle kinetics of Saccharomyces cerevisiae. Mol. Cell Biol. 8: 4675-4684.

Cross, F., L.H. Hartwell, C. Jackson, and J.B. Konopka. 1988. Conjugation in Saccharomyces cerevisiae. Annu. Rev. Cell Biol. 4: 429-457.

Dietzel, D. and J. Kurjan. 1987. The yeast SCG1 gene: a $\mathrm{G}_{\alpha}$-like protein implicated in the a- and $\alpha$-factor response pathway. Cell 50: 1001-1010.

Dolan, J.W., C. Kirkman, and S. Fields. 1989. The yeast STE12 protein binds to the DNA sequence mediating pheromone induction. Proc. Natl. Acad. Sci. 86: 5703-5707.

Errede, B. and G. Ammerer. 1989. STE12, a protein involved in cell-type-specific transcription and signal transduction in yeast is part of protein-DNA complexes. Genes Dev. 3: $1349-1361$.

Fields, S. and I. Herskowitz. 1985. The yeast STE12 product is required for expression of two sets of cell-type-specific genes. Cell 42: 923-930.

1987. Regulation by the yeast mating type locus of STE12, a gene required for cell-type-specific expression. Mol. Cell Biol. 7: 3818-3821.

Fields, S., D.T. Chaleff, and G.F. Sprague, Jr. 1988. Yeast STE7, STE11, and STE12 genes are required for expression of celltype-specific genes. Mol. Cell Biol. 8: 551-556.

Hagen, D.C. and G.F. Sprague, Jr. 1984. Induction of the yeast $\alpha$-specific $S T E 3$ gene by the peptide pheromone a-factor. $J$. Mol. Biol. 178: 835-852.

Hartig, A., J. Holly, G. Saari, and V.L. MacKay. 1986. Multiple regulation of STE2, a mating-type-specific gene of Saccharomyces cerevisiae. Mol. Cell Biol. 6: 2106-2114.

Hartwell, L. 1980. Mutants of Saccharomyces cerevisiae unresponsive to cell division control by polypeptide mating hormone. J. Cell Biol. 85: 811-822.

Hayes, T.E., P. Sengupta, and B.H. Cochran. 1988. The human c-fos serum response factor and the yeast factors GRM/ PRTF have related DNA-binding specificities. Genes Dev. 2: $1713-1722$.

Herskowitz, I. 1988. Life cycle of the budding yeast Saccharomyces cerevisiae. Microbiol. Rev. 52: 536-553.

Ito, H., Y. Fukuda, K. Murata, and A. Kimura. 1983. Transformation of intact yeast cells treated with alkali cations. $J$. Bacteriol. 153: 163-168.

Jahng, K.-Y., J. Ferguson, and S.I. Reed. 1988. Mutations in a gene encoding the $\alpha$ subunit of a Saccharomyces cerevisiae $G$ protein indicate a role in mating pheromone signaling. Mol. Cell. Biol. 8: 2484-2493.

Jarvis, E.E., K.L. Clark, and G.F. Sprague, Ir. 1989. The yeast transcription activator PRTF, a homolog of the mammalian serum response factor, is encoded by the MCM1 gene. Genes Dev. 3: 936-945.

Jenness, D.D., B.S. Goldman, and L.H. Hartwell. 1987. Saccharomyces cerevisiae mutants unresponsive to $\alpha$-factor pheromone: $\alpha$-Factor binding and extragenic suppression. Mol. Cell Biol. 7: 1311-1319.

Johnston, M. and R.W. Davis. 1984. Sequences that regulate the divergent GAL1-GAL10 promoter in Saccharomyces cerevisiae. Mol. Cell Biol. 4: 1440-1448.

Keleher, C.A., C. Goutte, and A.D. Johnson. 1988. The yeast cell-type-specific repressor $\alpha 2$ acts cooperatively with a non-cell-type-specific protein. Cell 53: 927-936.

Kronstad, J.W., J.A. Holly, and V.L. MacKay. 1987. A yeast operator overlaps an upstream activation site. Cell 50: 369-377.

McCaffrey, G., F.J. Clay, K. Kelsay, and G.F. Sprague, Jr. 1987. Identification and regulation of a gene required for cell fusion during mating of the yeast Saccharomyces cerevisiae. Mol. Cell Biol. 7: 2680-2690.

Maniatis, T., E. F. Fritsch, and J. Sambrook. 1982. Molecular cloning: A laboratory manual. Cold Spring Harbor Laboratory Press, Cold Spring Harbor, New York.

Miller, J.H. 1972. Experiments in molecular genetics. Cold Spring Harbor Laboratory Press, Cold Spring Harbor, New York.

Miyaijima, I., M. Nakafuku, N. Nakayama, C. Brenner, A. Miyajima, K. Kaibuchi, K. Arai, Y. Kaziro, and K. Matsumoto. 1987. GPA1, a haploid-specific essential gene, encodes a yeast homolog of mammalian $G$ protein which may be involved in mating factor signal transduction. Cell 50: $1011-1019$.

Nakayama, N., A. Miyajima, and K. Arai. 1985. Nucleotide sequences of STE2 and STE3, cell-type-specific sterile genes from Saccharomyces cerevisiae. EMBO /. 4: 2643-2648.

Nakayama, N., Y. Kaziro, K.-I. Arai, and K. Matsumoto. 1988. Role of STE genes in the mating factor signaling pathway mediated by GPA1 in Saccharomyces cerevisiae. Mol. Cell Biol. 8: 3777-3783.

Nash, R. G. Tokiwa, S. Anand, K. Erickson, and A.B. Futcher. 1988. The $\mathrm{WHI}^{+}$gene of Saccharomyces cerevisiae tethers cell division to cell size and is a cyclin homolog. EMBO J. 7: 4335-4346

Nasmyth, K. and D. Shore. 1987. Transcriptional regulation in the yeast life cycle. Science 237: 1162-1170.

Passmore, S., R. Elble, and B.-K. Tye. 1989. A protein involved in minichromosome maintenance in yeast binds a transcriptional enhancer conserved in eukaryotes. Genes Dev. 
3: $921-935$.

Sherman, F., G.R. Fink, and J.B. Hicks. 1986. Methods in yeast genetics. Cold Spring Harbor Laboratory Press, Cold Spring Harbor, New York.

Siliciano, P.G. and K. Tatchell. 1984. Transcription and regulatory signals at the mating type locus in yeast. Cell 37: 969978.

Sprague, G.F. Jr. and I. Herskowitz. 1981. Control of yeast cell type by the mating type locus. I. Identification and control of expression of the a-specific gene, BAR1. I. Mol. Biol. 153: $305-321$.

Sprague, G.F., Jr., L.C. Blair, and J. Thorner. 1983. Cell interactions and regulation of cell type in yeast Saccharomyces cerevisiae. Annu. Rev. Microbiol. 37: 623-660.

Strathern, J., J. Hicks, and I. Herskowitz. 1981. Control of cell type in yeast by the mating type locus: The $\alpha 1-\alpha 2$ hypothesis. J. Mol. Biol. 147: 357-372.

Tan, S., G. Ammerer, and T.J. Richmond. 1988. Interactions of purified transcription factors: Binding of yeast MAT $\alpha 1$ and PRTF to cell-type-specific, upstream activating sequences. EMBO I. 7: 4255-4264.

Teague, M.A., D.T. Chaleff, and B. Errede. 1986. Nucleotide sequence of the yeast regulatory gene $S T E 7$ predicts a protein homologous to protein kinases. Proc. Natl. Acad. Sci. 83: $7371-7375$.

Trueheart, J., J.D. Boeke, and G.R. Fink. 1987. Two genes required for cell fusion during yeast conjugation: Evidence for a pheromone-induced surface protein. Mol. Cell Biol. 7: 2316-2328.

Van Arsdell, S.W. and J. Thorner. 1987. Hormonal regulation of gene expression in yeast. In Transcriptional control mechanisms (ed. D. Granner, M.G. Rosenfeld, and S. Chang), pp. 325-332. Alan R. Liss, New York.

Whiteway, M., L. Hougan, L. Dignard, D.Y. Thomas, L. Bell, G.C. Saari, F.J. Grant, P. O'Hara, and V.L. MacKay. 1989. The STE4 and STE18 genes of yeast encode potential $\beta$ and $\gamma$ subunits of the mating factor receptor-coupled $G$ protein. Cell 56: 467-477.

Wilson, K.L. and I. Herskowitz. 1984. Negative regulation of STE6 gene expression by the $\alpha 2$ product of yeast. Mol. Cell Biol. 4: 2420-2427. 